\title{
CYTO-HISTOPATHOLOGICAL AND PCR CORRELATION OF CATTLE PULMONARY HYDATID DISEASE
}

\author{
FLORICA BĂRBUCEANU ${ }^{1,2 *}$, GABRIEL PREDOI ${ }^{2}$, CORINA-BEATRIS ANCUCEANU ${ }^{1}$, \\ STELIAN BĂRĂITĂREANU ${ }^{2}$, ȘTEFANIA-FELICIA BĂRBUCEANU ${ }^{3}$ \\ ${ }^{1}$ Institute for Diagnosis and Animal Health, 63 Dr Staicovici D. Nicolae Street, 050557, Bucharest, Romania \\ ${ }^{2}$ University of Agricultural Science and Veterinary Medicine, Faculty of Veterinary Medicine, 105 Splaiul Independenței, \\ 050097, Bucharest, Romania \\ ${ }^{3}$ Department of Organic Chemistry, "Carol Davila" University of Medicine and Pharmacy, Faculty of Pharmacy, 6 Traian \\ Vuia Street, 020956, Bucharest, Romania
}

*corresponding author: florica.barbuceanu@idah.ro

Manuscript received: May 2020

\begin{abstract}
Hydatid disease is a severe zoonosis caused by metacestodes (the larval stage of a tapeworm) of the genus Echinococcus. Considering the complex ultrastructure of the cyst, the cyto-histopathological analysis of the hydatid cyst layers requires the use of various histochemical staining techniques. This paper is a cyto-histopathological and PCR analysis of the uninfected and infected pulmonary hydatid cyst membrane structures, conducted between 2009 and 2019 on a total of 2123 lung samples of cattle 2-18 years old. The open infected hydatid cyst, identified in lungs from cattle, can be considered, from the cyto-histopathological point of view, as a diffuse granulomatous hydatid proliferation. PCR was a reliable and valuable tool in the E. granulosus rapid diagnosis.
\end{abstract}

\section{Rezumat}

Hidatidoza este o zoonoză severă cauzată de metacestode (stadiul larvar al unei tenii) din genul Echinococcus. Având în vedere ultrastructura complexă a chistului, analiza cito-histopatologică a straturilor chistului hidatic necesită utilizarea mai multor tehnici de colorare histochimică. Această lucrare este o analiză cito-histopatologică și PCR a structurilor membranei chistului hidatic pulmonar neinfectat și infectat, realizată între anii 2009 și 2019 pe un total de 2123 probe de pulmon, de la bovine cu vârsta cuprinsă între 2 și 18 ani. Chistul hidatic infectat deschis, identificat în plămâni de la bovine, poate fi considerat, din punct de vedere citohistopatologic, o proliferare hidatică granulomatoasă difuză. În studiul nostru, tehnica PCR a fost un instrument de încredere și valoros pentru diagnosticul rapid al E. granulosus.

Keywords: hydatidosis, histochemical staining, cyto-histopathology, PCR

\section{Introduction}

Hydatid disease, or Echinococcosis, is a severe zoonosis with a long history in Europe, which still produces major outbreaks in certain communities and numerous debates in today's scientific world [12, 15 , 30]. Both human and bovine hydatid diseases are caused by metacestodes (the larval stage of a tapeworm) of the genus Echinococcus, found in the small intestines of carnivores (the definitive hosts) [10, 23]. Humans are only incidentally infected, for which the main sites of hydatid cysts are the liver, lung, and brain [23].

In Romania, the incidence of human and bovine hydatidosis appears to be one of the highest in Europe $[5,10,23]$. This requires the establishment and implementation of sustained prevention and control programs, including the use of new surgical therapeutic techniques in human hydatidosis $[19,28,31,32]$ and new prevention programs in bovine hydatidosis $[2,4$, $11,17]$.
It is necessary to increase the knowledge of the interaction between the parasite and animal host tissue, mainly for a better surgical approach. Between the host tissue and the parasite is a very close interaction developed from the early stages of the hydatid cyst to the complete development of all cyst layers (membranes): the pericyst (the outermost layer of hydatid cyst contains almost entirely host cells), the middle laminated membrane and the inner germinal layer [16].

Considering the complex ultrastructure of the cyst, the cyto-histopathological analysis of the hydatid cyst layers requires the use of various histochemical staining techniques. The most often used stain is haematoxylin and eosin (H\&E), a staining method important for diagnosing pathology, which stains nuclear components from blue to dark purple and cytoplasm and most connective tissue fibres in orange, pink or red [14]. Another staining method is the modified Masson's trichrome designed to selectively identify collagenous connective tissue fibres (stained blue), and to differentiate them from the erythrocytes, fibrin, 
cytoplasm of cells and muscle (stained red); nuclei are stained purple-black [22]. One of the most widely used histochemical methods is the periodic acidSchiff (PAS) reaction, used to detect polysaccharides, mucosubstances, and mucins in tissues. Periodic acid is a strong oxidising agent used to cleave the vicinal diols of sugars and yield aldehydes. The Schiff reagent reacts with aldehydes to give a purple-magenta colour. In most protocols, PAS is used in combination with the alcian blue staining to a better distinction of the neutral mucins (stained bright magenta) from the acid mucins (stained deep blue) [1, 21].

Polymerase chain reaction (PCR) has been used for the detection of species and genotypes (strains) of Echinococcus in various biological samples [7, 25, 26]. The aim of this research was the cyto-histopathological and PCR analysis of the uninfected and infected pulmonary hydatid cyst membrane structures in cattle.

\section{Materials and Methods}

\section{Biological samples}

The results of 2123 cattle aged 2 - 18 years with pulmonary hydatid disease at the post-mortem inspection were analysed between 2009 and 2019.

Suspected cystic samples were detached from the cattle lungs, placed in sterile bags, identified, refrigerated, and shipped within 3 hours to the Institute for Diagnosis and Animal Health, Bucharest, Romania for further examination.

\section{Cytopathological examination}

The cytologic diagnosis of echinococcosis consisted in fine-needle aspiration of lung hydatid cyst, centrifugation at $1000 \mathrm{rpm}$ for 2 minutes, and the smear sediment examination under a microscope. Both unstained wet

and Haematoxylin (isotonic solution, 1\%) stained mounts of hydatid fluid sediment were examined.

\section{Histopathological examination}

The histopathological examination used a formalinfixed paraffin-embedded tissue sample of hydatid cysts. Paraffin block slides at the desired thickness (4 - $5 \mu \mathrm{m})$ were dewaxed and then stained with haematoxylin and eosin (H\&E), modified Masson, Periodic Acid Schiff (PAS) and PAS-Alcian blue (PAS-AB) methods for light microscopic examination. The sections were examined and photographed with an Olympus BX5 microscope to observe histopathological aspects of interest.

Detection of E. granulosus by polymerase chain reaction $(P C R)$

The PCR used samples of pulmonary hydatid cyst germinal layer. The samples were crushed individually in the Petri dish with a scalpel blade and a tweezers, and $\sim 100 \mathrm{mg}$ of each sample was loaded into the lysis tubes, over which $900 \mu \mathrm{L}$ phosphate buffer saline (PBS) 1X was added. The contents were homogenized with the MagNA Lyser Instrument (Roche Diagnostics, Germany) according to the manufacturer's recommendations, and subsequently centrifuged for $1 \mathrm{~min}$ at 13,000 rpm for supernatant expression. DNA extraction used $200 \mu \mathrm{L}$ supernatant and PureLink Genomic DNA Mini Kit (Invitrogen, Thermo Fisher Scientific, USA), by following of manufacturer's instructions. The preparation of the reaction mix and its coupling with the previously extracted DNA were performed with the GoTaqDNA Polymerase (Promega, USA) amplification kit and the specific EgO/DNA-IM1 primer set [22], in a final volume of $25 \mu \mathrm{L} /$ sample (Table I).

Table I

Components of the PCR reaction mix for the detection of E. granulosus

\begin{tabular}{|c|c|}
\hline Reagents & Volume $(\mu \mathrm{L} /$ sample $)$ \\
\hline Nuclease-Free Water & 8.375 \\
\hline GoTaq Reaction Buffer & 5.0 \\
\hline PCR Nucleotide Mix, 10mM each & 0.5 \\
\hline $\begin{array}{l}\text { upstream primer } 20 \mathrm{pmol} / \mu \mathrm{L} \\
5^{\prime} \text {-TCATATTTGTTTGAGKATYAGTKC-3' [22] }\end{array}$ & 0.5 \\
\hline $\begin{array}{l}\text { downstream primer } 20 \mathrm{pmol} / \mu \mathrm{L} \\
\text { 5'-GTAAATAAMACTATAAAAGAAAYMAC-3' [22] }\end{array}$ & 0.5 \\
\hline GoTaq DNA Polymerase (5 U/ $\mu \mathrm{L})$ & 0.125 \\
\hline Template DNA & 10.0 \\
\hline
\end{tabular}

The thermal cycling protocol had an initial denaturation step for $2 \mathrm{~min}$ at $95^{\circ} \mathrm{C}, 45$ cycles of a denaturation step at $94^{\circ} \mathrm{C}$ for $45 \mathrm{sec}$, an annealing step at $50^{\circ} \mathrm{C}$ for $45 \mathrm{sec}$, an extension step at $72^{\circ} \mathrm{C}$ for $1 \mathrm{~min}$, and final extension at $72^{\circ} \mathrm{C}$ for $5 \mathrm{~min}$. Soak step at $4^{\circ} \mathrm{C}$ for an indefinite time. The amplification products were separated by agarose gel electrophoresis (1.5\%) using $1.2 \mathrm{~g}$ agarose, $80 \mathrm{~mL} 1 \times$ tris-acetate-EDTA (TAE) buffer, and $5 \mu \mathrm{L}$ of $10 \mathrm{mg}$ ethidium bromide (EtBr)/ $\mathrm{mL}$. As migration buffer $1 \times$ TAE buffer $+10 \mu \mathrm{L} \mathrm{EtBr}$ $10 \mathrm{mg} / \mathrm{mL}$ was used. $10 \mu \mathrm{L}$ of sample (amplified DNA) was homogenized with $3 \mu \mathrm{L}$ of loading buffer on a Parafilm foil. $10 \mu \mathrm{L}$ of the resulting mixture was charged into the wells of the agarose gel. The migration parameters have been set to $100 \mathrm{~V}, 0.5 \mathrm{~A}$ and $35 \mathrm{~min}$. In the first well molecular size marker EZ Load 100 bp Molecular Ruler (BioRad, USA) was loaded, and in the next wells the samples and the controls $-\mathrm{E},+\mathrm{E}$, $-\mathrm{C}$ and $+\mathrm{C}$ (Figure 1). The positive result shows a 285 base pairs (bp) amplification fragment corresponding to the partial sequence of the E. granulosus mitochondrial gene of the cytochrome oxidase CO1 [8]. 


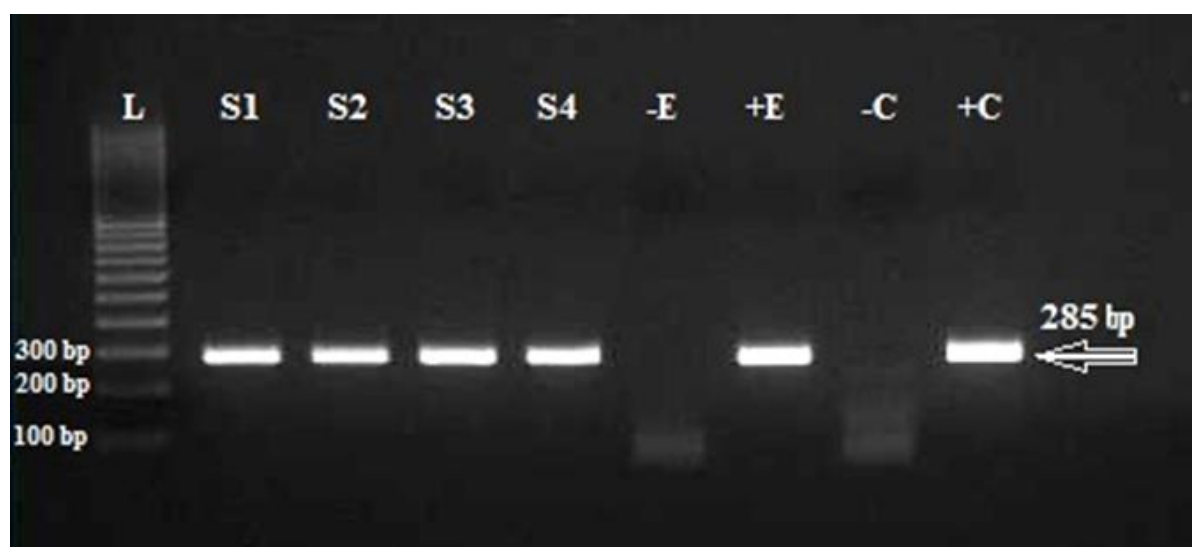

Figure 1.

Agarose gel electrophoresis of the PCR product CO1 gene fragment of Echinococcus granulosus at 285 bp in cattle pulmonary hydatid disease

L: Ladder 100 bp; S1 - S4: positive samples and $-\mathrm{E},+\mathrm{E},-\mathrm{C},+\mathrm{C}$ : negative and positive controls

\section{Results and Discussion}

In cattle, hydatid cysts grow slowly, usually in several years [29], but the initial development of the cyst is achieved in $10-14$ days and the formation of a complete fertile cyst with numerous protoscoleces in at least 10 months [20, 29]. Fertility of hydatid cysts is an important factor in the life cycle of Echinococcus species. The fertility rate is influenced by several environmental, host, and cyst factors [13].

The most important cyst factors are site, size and type of the cyst. In infections with cattle strain, hydatid cysts are mainly in the lungs and morphologically can be unilocular or multilocular, varying greatly in size and shape [24]. The bacterial infection can lead to protoscoleces degeneration and sterilization of the infected hydatid cysts [13], but only a few studies described the bacterial infections of hydatid cysts $[9,13,18]$.

The cytological and histological exam of uninfected and infected hydatid cysts (Figures 2, 3 and 4) revealed quite different morphological patterns (Table II), but the protoscoleces were observed in both types of cysts.

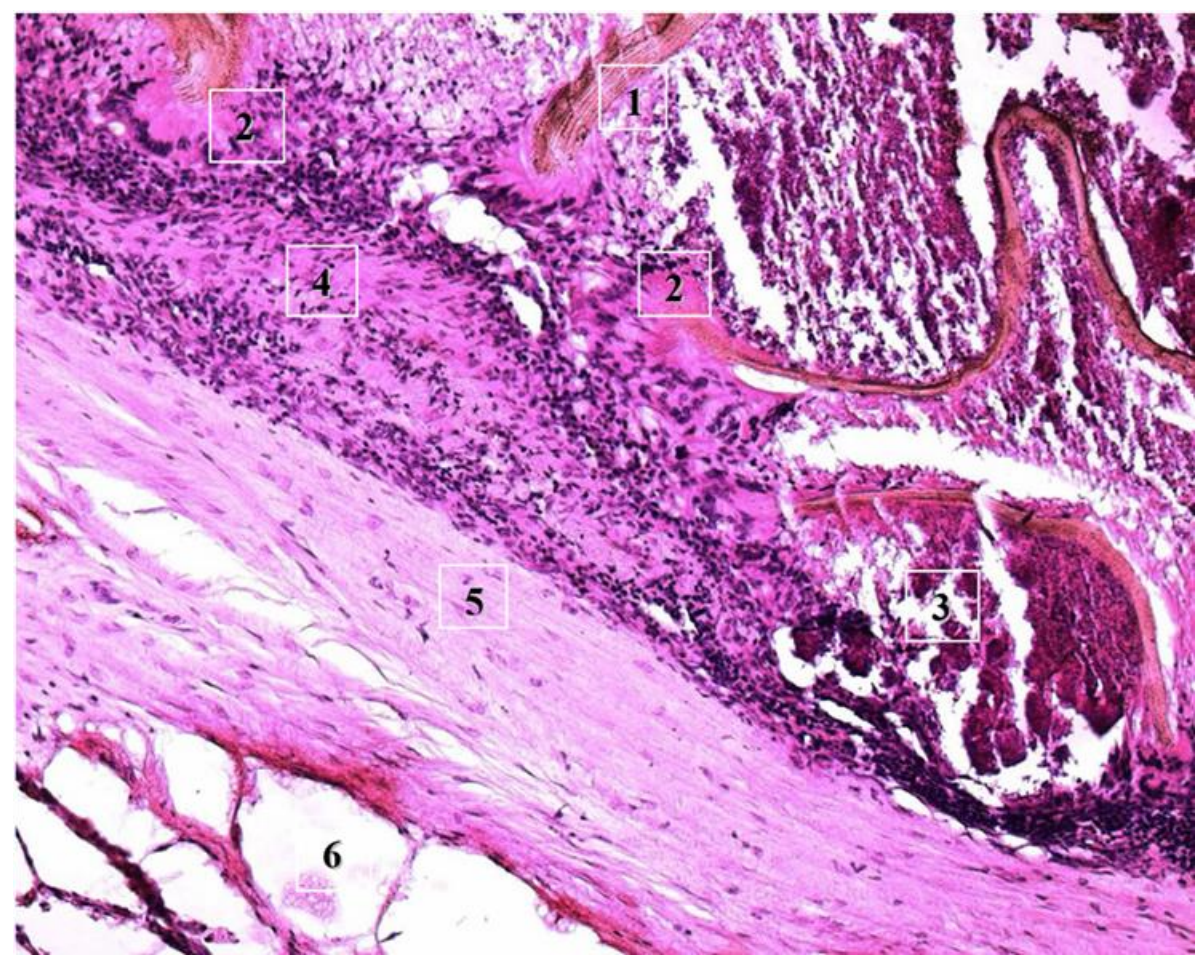

Figure 2.

Infected hydatid cyst: 1 - proliger-cuticular membrane; 2 - polymorph cellular population; 3 - necrosis; 4 - multinucleated giant cells; 5 - fibrous capsule around the cysts; 6 - emphysema Cattle pulmonary hydatid disease. H\&E, $\times 600$ 


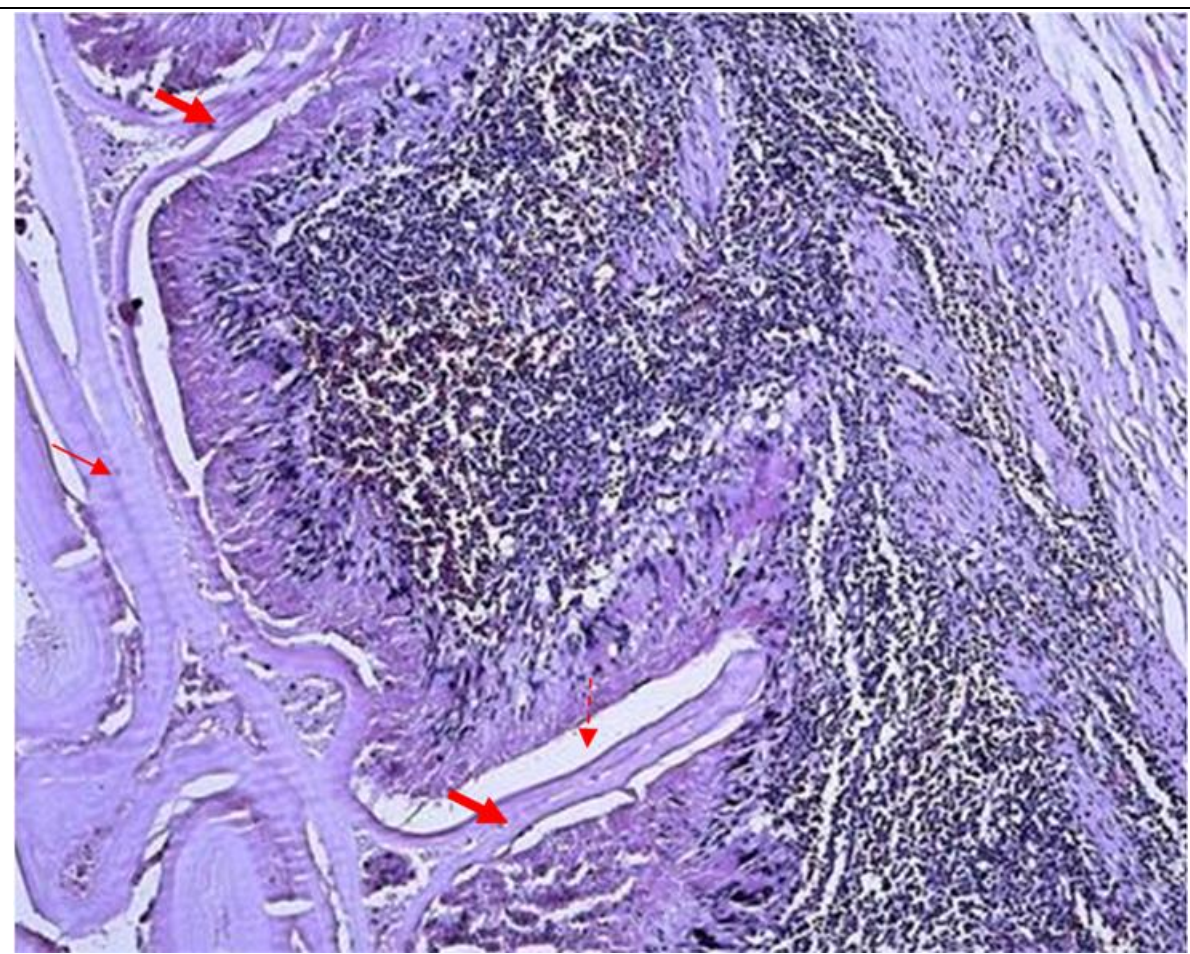

Figure 3.

Infected hydatid cyst: proliger-cuticular membrane (thin arrow); proliger-cuticular membrane "spurs" in the pericystic area (thick arrow); subcuticular lacunar layer that delimits proliger-cuticular and pericystic membranes (dotted arrow)

Cattle pulmonary hydatid disease. Modified Masson, $\times 100$

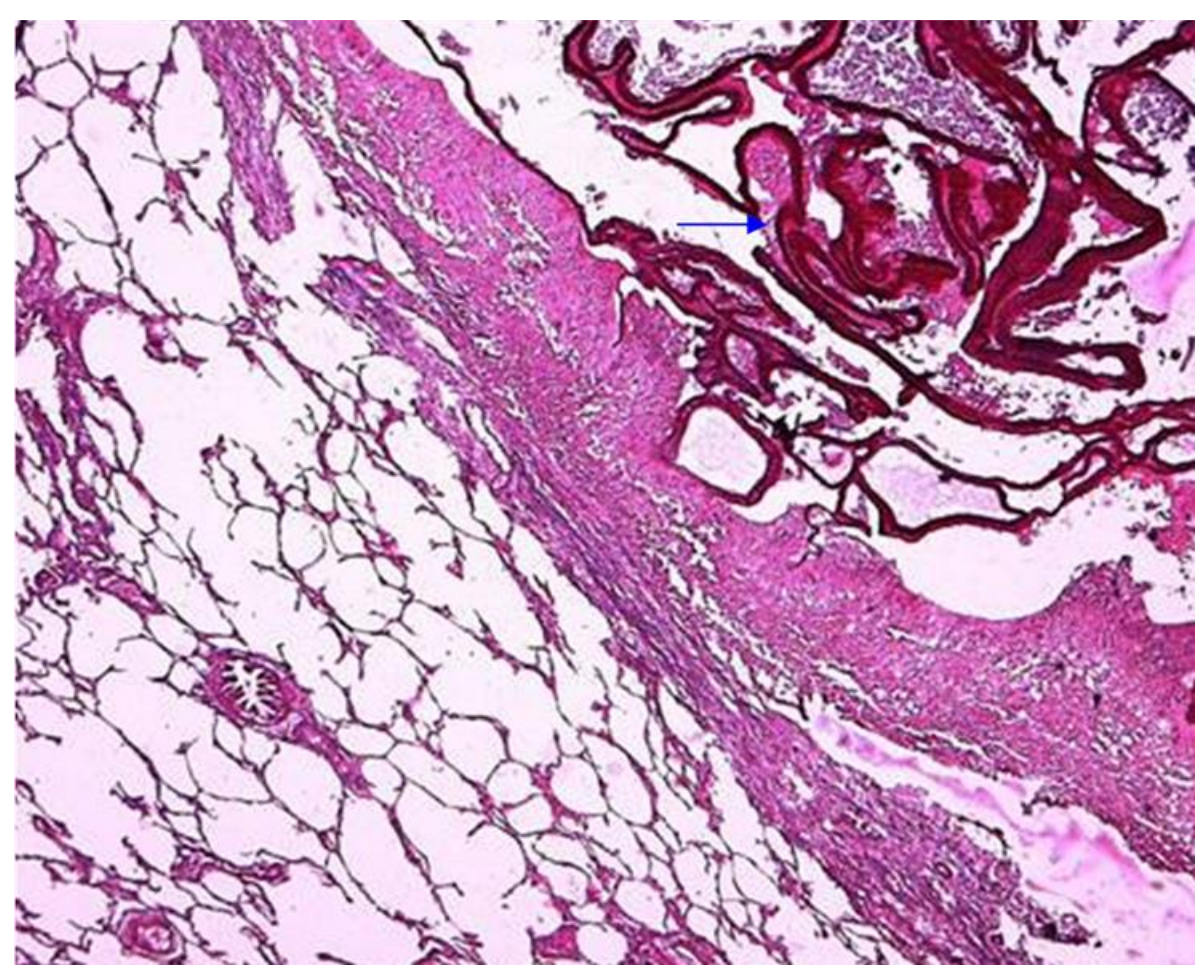

Figure 4.

Larvae germinal elements intense PAS-positive (arrow) Cattle pulmonary hydatid disease. PAS, $\times 50$

Also, in uninfected hydatid cysts, some vesicular structures presented structural configurations of preprotoscoleces (e.g.., rostral apparatus, internal canalicular excreting network, germinal-cuticular membrane system). In the infected hydatid cysts, the structural destructions are oedematous and necrotic alterations, 
haemorrhages and calcifications. The delimiting layer structures of the larvae germinal elements alter their topographic histological rapports, germinal elements surpass the structural limits of the primary hydatid cyst and develop new hydatid centres in other layer structures (e.g., pericystic membrane) [6,27].

Table II

Main cytological and histological morphology in cattle pulmonary hydatid disease

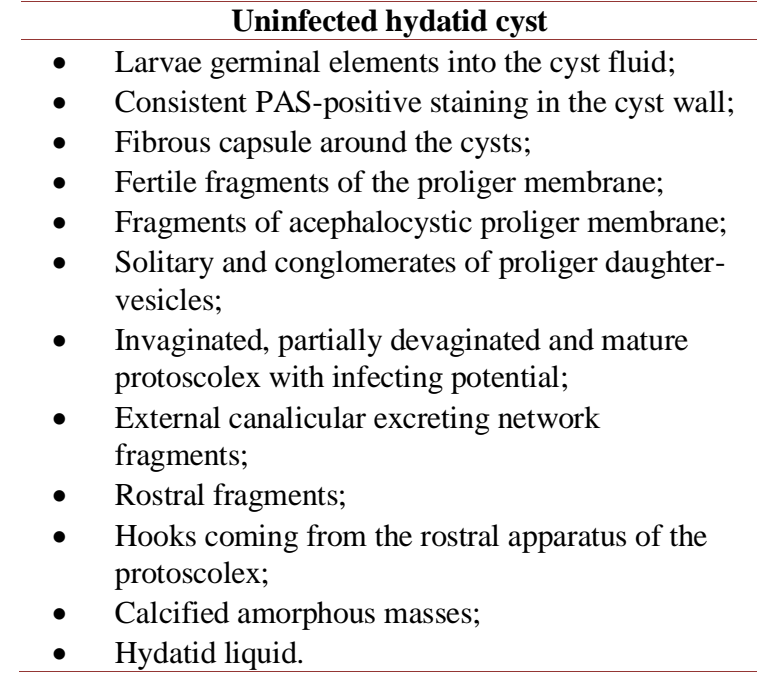

The new cystic centres which were developed into the layer structure and in the proximity of the infected pulmonary hydatid cysts together with the overlapping inflammatory process constitute a complex pulmonary granulomatous hydatid lesion, with the following characteristics: (1) opened hydatid cyst; (2) inflammatory process with cellular reactivity, predominantly mononuclear and neutrophilic and eosinophilic granulocytes reactivity; (3) disorganization of the proliger-cuticular layer, pericystic layer, and epithelioid-giant and polymorph nuclear cell layers architectonics; (4) identification of free and phagocyted hydatid germinal elements in the interlayer spaces; (5) the peripheral secondary hydatids constituted and forming, with epithelioidgiant cellular and polymorph cellular reactivity. In our previous study [3], we considered the cattle pulmonary granulomatous hydatid disease a model of study for human medicine in videothoracoscopy and non-invasive and minimal-invasive surgical technique investigations.

Several DNA methods are available for the identification of E. granulosus strains in intermediate hosts. The PCR analyses revealed that all hydatid cysts were of E. granulosus. Molecular analysis concomitant to histopathological examinations is useful in the diagnosis of cattle pulmonary hydatid disease.

\section{Conclusions}

The technique used has clarified the differences in structure and composition between the uninfected and infected cyst. In the bovine hydatid pulmonary infection, larvae germinal elements were present into the cyst fluid of the uninfected and infected hydatids, and in the lacunar hydatid liquid of the interlayer spaces of the open infected hydatid cysts. In cattle
- Larvae germinal elements into the cyst fluid;

- Consistent PAS-positive staining in the cyst wall;

- Fibrous capsule around the cysts;

- Larvae germinal elements into the lacunar hydatid liquid of the interlayer spaces;

- Fragmented, discontinuous proliger-cuticular membrane;

- Polymorph cellular population with giant cells, eosinocytes, plasmocytes and/or neutrophilic granulocytes;

- Subcapsular inflammatory cell infiltration, eosinophil leucocyte accumulation into the cyst lumen and inflammatory cell infiltration into adjacent organ parenchyma;

- Necrosis and calcification areas in the restant intracystic spaces and infected hydatid layer structures;

- Emphysema. lungs, the open infected hydatid cyst can be cytohistopathologically considered a diffuse granulomatous hydatid proliferation. The PCR analyses proved to be a reliable and valuable tool in the E. granulosus rapid diagnosis. The results obtained in cattle pulmonary hydatid disease study recommend the cattle as a valuable animal model for the diagnostic and therapy of the human infection with E. granulosus.

\section{Conflict of interest}

The authors declare no conflict of interest.

\section{References}

1. Aterman K, Norkin S, The Periodic Acid - Schiff reaction. Nature, 1963; 197: 1306.

2. Baraitareanu S, Vidu L, The preventive medicine of bovine viral diarrhoea - mucosal disease in dairy farms: A review. Revista Romana de Medicina Veterinara, 2019; 29(2): 61-64.

3. Barbuceanu F, Alexandru N, Delimitative membrane structures of larvar germinative elements in pulmonary hydatidosis in cattle. Scientific Works, C series, 2009; LV(1): 13-21.

4. Barbuceanu F, Diaconu C, Stamate D, Raita S, Popovici A, Georgescu B, Belu C, Predoi G, Histopathological study of brain from cattle with nervous symptomatology. Agriculture and Agricultural Science Procedia, 2015; 6: 287-292.

5. Barbuceanu F, Alexandru N, Dida I, Contributions to the study of the embryogenesis of tapeworm Echiococcus granulosus. Revista Romana de Medicina Veterinara, 1999; 10 (3 (Supp.)): 374-374, (available in Romanian).

6. Barbuceanu F, Cyto-histopathological Study of the Hydatid Cyst in Cattle, PhD thesis, USAMV, Bucharest, 2005, (available in Romanian).

7. Boufana B, Umhang G, Qiu J, Chen X, Lahmar S, Boué F, Jenkins D, Craig P, Development of three PCR 
assays for the differentiation between Echinococcus shiquicus, E. granulosus (G1 genotype), and $E$. multilocularis DNA in the co-endemic region of Qinghai-Tibet plateau, China. Am J Trop Med Hyg., 2013; 88(4): 795-802.

8. Cabrera M, Canova S, Rosenzvi M, Guarnera E, Identification of Echinococcus granulosus eggs. Diagn Microbiol Infect Dis., 2002; 44(1): 29-34.

9. Chang R, Higgins M, Dilisio R, Hawasli A, Camaro LG, Khatib R, Infected hepatic Echinococcus cyst presenting as recurrent Escherichia coli empyema. Ann Thorac Surg., 1993, 55(3): 774-775.

10. Coman A, Coman I, Observations regarding the epidemiology of hydatidosis in cattle livestock. Revista Romana de Medicina Veterinara, 2019; 29(2): 11-14.

11. Ducrotoy MJ, Azami HY, El Berbri I, Bouslikhane M, Fihri OF, Boue F, Petavy AF, Dakkak A, Welburn $\mathrm{S}$, Bardosh KL, Integrated health messaging for multiple neglected zoonoses: approaches, challenges and opportunities in Morocco. Acta Trop., 2015; 512: $17-25$

12. Eckert J, Thompson RC, Historical aspects of echinococcosis. Adv Parasitol., 2017; 95: 1-64.

13. Fallah M, Kavand A, Yousefi Mashouf R, Infected hydatid cysts bacteria in slaughtered livestock and their effects on protoscoleces degeneration. Jundishapur J Microbiol., 2014; 7(6): e10135: 1-5.

14. Gamble M, The hematoxylins and eosin. In: Bancroft J \& Gamble M, editors, Theory and Practice of Histological Techniques, $6^{\text {th }}$, Churchill Livingston, Philadelphia, PA, 2008; 121-130.

15. Golematis B, Hydatid Disease: History, etiology, epidemiology, epizootiology, locations, and prevention. Surg Annu., 1978; 10: 359-386.

16. Golzari SE, Sokouti M, Pericyst: The outermost layer of hydatid cyst. World J Gastroenterol., 2014; 20(5): 1377-1378.

17. Heath DD, Robinson C, Shakes T, Huang Y, Gulnur T, Shi BX, Zhang ZZ, Anderson GA, Lightowlers MW, Vaccination of bovines against Echinococcus granulosus (cystic echinococcosis). Vaccine, 2012; 30(20): 3076-3081.

18. Masterton RG, O'Doherty MJ, Eykyn SJ, Streptococcus milleri infection of a hepatopulmonary hydatid cyst. Eur J Clin Microbiol., 1987; 6(4): 414-415.

19. Mihaila DE, Poteca TD, Poteca AG, Matei C, Ciuca I, Tampa M, The use of argon laser in medical treatment. Rev Chim. (Bucharest), 2014; 65(3): 369-371.

20. Mitrea IL, Research Regarding Immunodiagnostics, Immune Response and Immune Prophylaxis in Hydatidosis in Ruminants, PhD thesis, USAMV Bucharest, 1998; (available in Romanian).

21. Myers R, Special Stain Techniques for the Evaluation of Mucins, www.leicabiosystems.com/knowledgepathway/.
22. Otali D, Fredenburgh J, Oelschlager DK, Grizzle WE, A standard tissue as a control for histochemical and immunohistochemical staining. Biotech Histochem., 2016; 91(5): 309-326.

23. Papancea A, Georgescu SO, Vintila D, Lupascu CU, Timofte D, Fotea V, Petrariu F, Ciuntu BM, Percutaneous Aspiration-Injection-Reaspiration of Hepatic Cystic Echinococcosis. Rev Chim. (Bucharest), 2019; 70(9): 3220-3224.

24. Rausch RL, Life cycle patterns and geographic distribution of Echinococcus species, In: Thompson R.C.A. \& Lymbery A.L., editors, Echinococcus and Hydatid Disease, CAB International, Wallingford, Oxon, 1995; 88-134.

25. Santucciu C, Masu G, Mura A, Peruzzu A, Piseddu T, Bonelli P, Masala G, Validation of a one-step PCR assay for the molecular identification of Echinococcus granulosus sensu stricto G1-G3 genotype. Mol Biol Rep., 2019; 46: 1747-1755.

26. Schneider R, Gollackner B, Edel B, Schmid K, Wrba F, Tucek G, Walochnik J, Auer H, Development of a new PCR protocol for the detection of species and genotypes (strains) of Echinococcus in formalin-fixed, paraffin-embedded tissues. Int J Parasitol., 2008; 38: 1065-1071.

27. Singh BB, Sharma R, Sharma JK, Mahajan V, Gil JP, Histopathological changes associated with $E$. granulosus echinococcosis in food producing animals in Punjab (India). J Parasit Dis., 2016; 40(4): 9971000.

28. Spataru RI, Popoiu MC, Ivanov M, Foregut duplication cyst associated with esophageal atresia-one-stage neonatal surgical repair. Indian J Surg., 2015; 77(Sup. 1): 52-55.

29. Thompson RCA, Biology and Systematics of Echinococcus, In: Thompson RCA \& Lymbery AL, editors, Echinococcus and Hydatid Disease, CAB International, Wallingford, Oxon, 1995; 10-22.

30. Vuitton DA, Wang Q, Zhou HX, Raoul F, Knapp J, Bresson-Hadni S, Wen H, Giraudoux P, A historical view of alveolar echinococcosis, 160 years after the discovery of the first case in humans. 1 . What have we learnt on the distribution of the disease and on its parasitic agent?. Chin Med J (Engl.), 2011; 124(18): 2943-2953.

31. Xu MQ, Hydatid disease of the lung. Am J Surg., 1985; 150(5): 568-573.

32. Zia Haghi S, Mirsadraee M, Bagheri R, Bronchoscopic Findings in patients with hydatid cyst of the lung. Does it correlate with radiologic findings?. J Bronchol., 2006; 13(3): 28-131. 